\title{
Analisis Peran Kepala Daerah terhadap Perubahan Kompetensi Ekonomi Warga Pesisir Batu Belubang-Bangka Tengah
}

\author{
Kevin Sabri ${ }^{1} \&$ Ahmad Kurniadi $^{2}$ \\ ${ }^{12}$ Universitas Bangka Belitung \\ Email: sabrikevin961@gmail.com \\ kurniadiahmad498@gmail.com
}

\begin{abstract}
Abstrak
Pertumbuhan ekonomi dapat dibuktikan dari kecerdasan seorang kepala daerah dalam meningkatkan perekonomian daerahnya sekaligus mengunakan perannya sebagai kepala daerah untuk memberikan asumsi ekonomi pangan terhadap kebutuahan rakyatnya. Tujuan penelitian ini untuk mengetahui analisis peran kepala daerah terhadap perubahan kompetensi ekonomi warga pesisir Batu Belubang - Bangka Tengah. Kompetensi ekonomi merupakan bentuk dari sarana dan prasarana suatu pembangunan di suatu daerah yang kemudian membentuk ekonomi yang berkualitas dalam jangka panjang. Maka pemilihan kepala daerah suatu harapan masyarakat bagi pertumbuhan ekonomi untuk kemajuan daerah tersebut dengan hal ini tentu harus diiringi dengan partisipasi warga dalam pilkada. Adapun penelitian ini mengunakan metode penelitian deskriptif kualitatif dengan tujuan untuk mengetahui peran kepala daerah terhadap perubahan kompetensi ekonomi warga pesisir Batu Belubang - Bangka Tengah. Adapun hasil penelitian ini berdasarkan data penduduk tahun 2014 berjumlah 1.106 KK dan 3.238 penduduk. 1.619 jiwa yang terkonfirmasi pertumbuhan ekonominya ketergantungan dari pekerjaan nelayan dan tidak adanya sarana dan prasarana bantuan dari kepala daerah.
\end{abstract}

Kata Kunci: partisipasi, pilkada, sosialisasi, pemilu, ekonomi-politik

\begin{abstract}
Economic growth can be proven from the intelligence of a regional head in improving his regional economy while at the same time using his role as a regional head to provide food economic assumptions on the needs of his people. The purpose of this study was to determine the analysis of the role of regional heads in changing the economic competence of the residents of Batu Belubang - Bangka Tengah. Economic competence is a form of facilities and infrastructure of a development in an area which then forms a quality economy in the long run. Then the election of a regional head of a community's hope for economic growth for the advancement of the region with this certainly must be accompanied by citizen participation in the elections. The research uses a descriptive qualitative research method with the aim to find out the role of regional heads in changing the economic competence of the residents of Batu Belubang - Bangka Tengah. The research results in this journal are based on 2014 population data of 1,106 households and 3,238 residents. 1,619 people whose economic growth is confirmed to be dependent on the work of fishermen and the lack of facilities and infrastructure for assistance from the regional head.
\end{abstract}

Keywords: participation, elections, socialization, elections, political-economy

\section{PENDAHULUAN}

Banyak yang mengunakan media sosial terhadap pilkada tahun 2020 di masa kampanye paslon di Bangka tengah, dari kedua paslon ini dimana kita lihat samasama mengunakan pencitraannya dalam mengunakan media sosial yaitu fecebook untuk memberikan kegemparan setiap kandidat. Paslon satu mengunakan media sosial untuk memamerkan dengan cara memberikan bantuan terhadap masyarakat 
miskin dan terdampak wabah corona sedangkan paslon dua mengunakan media sosial untuk menciptakan wibawa bahwa dirinya seperti masyarakat biasa dengan mengunakan sandal jepitnya untuk terlihat berwibawa, dengan hal ini semata-mata dari kedua paslon ini mengunakan media sosialnya untuk menarik masa pada intinya. Begitulah media sosial digunakan untuk kepentingan semata. Hal ini pemilihan kepala daerah di Bangka tengah. Masa-masa kampanye ramai dengan mengunakan media facebook yang digemparkan dengan wajah mereka para paslon atau kandidat untuk mendapatkan kursi sebagai bupati Bangka Tengah.

Pemilu juga merupakan salah satu usaha untuk mepengaruhi rakyat secara persuasif (tidak memaksa) dengan melakukan kegiatan retorika, hubungan publik, komunikasi masa, lobi serta membentuk kemajuan daerah dari pada itu mebentuk budaya lokal dalam proses peningkatan sarana dan prasarana suatu daerah sehingga saling bekerja sama antara pimpinan nasional dan lokal. Kemudian para pemilih dalam pemilu juga disebut konstituen, dan kepada merekalah para peserta pemilu menawarkan janji-janji dan program-programnya pada masa kampanye. Kampanye dilakukan selama waktu yang telah ditentukan, menjelang hari pemungutan suara. Maka dari itu masyarakat harus memilih calon kepala daerahnya dengan hati nurani dengan tidak adanya paksaan orang lain apalagi paksaan calon kepala daerah dengan mengunakan jalan yang tidak benar seperti politik uang.

Pada hari pemungutan suara, para pemilih biasanya akan datang ke TPS (tempat pemungutan suara) di sekitar lingkungan tempat tinggal mereka. Mereka kemudian akan memilih calon pilihannya di dalam bilik-bilik suara yang telah disediakan oleh panitia. Setelah proses pemungutan suara dilakukan, proses penghitungan suarapun akan dimulai. Pemenang pemilu ditentukan oleh peraturan atau sistem penentuan pemenang yang sebelumnya telah diterapkan dan disetujui. Pemilihan umum merupakan sarana kedaulatan rakyat untuk ikut serta dalam pembangunan negara, setiap warga negara Indonesia yang memenuhi syarat secara hukum memiliki kesempatan yang sama dalam pemilu.

Dengan demikian pemuda sebagai agen perubahan juga dalam mesukseskan pilkada maka partisipasi generasi muda dalam bidang politik sering kali menjadi bahan perdebatan. Generasi muda sering kali dianggap sebagai kelompok masyarakat yang paling tidak peduli dengan persoalan politik, mereka sering kali mengalami putus hubungan dengan komunitasnya, tidak berminat pada proses dan persoalan politik, memiliki tingkat kepercayaan rendah pada politisi serta sinis terhadap berbagai lembaga politik dan pemerintahan. Pandangan ini sering kali dibenarkan dengan data yang menunjukkan bahwa generasi muda yang bergabung ke dalam partai politik relatif sedikit, dan mereka cenderung memilih menjadi golput pada pemilu. Namun di lain pihak, generasi muda di Indonesia menjadi pelopor penggunaan media sosial yang terkenal sangat intensif. Berbagai lembaga riset internasional melaporkan bahwa jumlah pengguna facebook di Indonesia adalah yang terbesar kedua di dunia, dan twitter pada posisi ketiga terbesar di dunia.

Memandang pemilu sebagai lambang, sekaligus tolak ukur demokrasi. Hasil pemilu dan diselengarakan dalam suasana keterbukaan dengan kebebasan berpendapat dan kebebasan berserikat, diangap mencerminkan akurasi partisipasi serta aspirasi masyarakat. Pemilihan umum tidak merupakan satu-satunya tolak ukur dan pemilu dilengkapi dengan pengukuran. Menurut Undang-Undang Republik lindonesia Nomor 42 Tahun 2008, pemiliahn umum secara langsung merupakan sarana pelaksanaan kedaulatan rakyat guna menghasilkan pemerintahan negara 
yang demokratis berdasarkan Pancasila dan Undang-Undang Dasar Negara Republik Indonesia Tahun 1945.

Penelitian ini bertujuan untuk meneliti tentang peran kepala daerah terhadap perubahan kompetensi ekonomi masyarakat daerah yang terkhusus warga Batu Belubang - Bangka Tengah. Karena setiap program yang dilontarkan kepala daerah harus sesuai dengan janji sebelum menjadi kepala daerah sehingga mengundang kepercayaan warga untuk ikut partisipasi dalam pemilihan kepala daerah dan warga berharap pergantian kepala daerah bertujuan untuk ada perbaikan-perbaikan dalam hal kompetensi ekonomi maupun kemajuan desa tersebut sehingga warga percaya politik ini mampu memberikan kesejahteraan bagi warga desanya.

Pemilihan kepala daerah (pilkada) dilakukan secara langsung oleh penduduk daerah administratif setempat yang memenuhi syarat. Pemilihan kepala daerah dilakukan sepaket bersama dengan wakil kepala daerah. Kepala daerah dan wakil kepala daerah yang dimaksud mencakup gubernur dan wakil gubernur untuk provinsi, bupati dan wakil bupati untuk kabupaten, wali kota dan wakil walikota untuk kota. Kemudian sebelum tahun 2005 kepala daerah dan wakil kepala daerah dipilih oleh dewan perwakilan rakyat daerah (DPRD). Sejak berlakuknya Undang-Undang Nomor 32 Tahun 2004 tentang Pemerintahan Daerah (Nuryanti 2015).

Kemajuan desa maupun perubahan ekonomi pada masyarakat daerah tergantung bagaimana kebijakan kepala daerah dalam mengkoordinir suatu pertumbuhan ekonomi pada masyarakat suatu wilayah. Mengapa demikian karena kepercayaan masyarakat daerah atau disebut desentralisasi adalah penyerahan kekuasaan pemerintah oleh pemerintah pusat kepada daerah otonom berdasarkan asas otonomi. Pengertian ini sesuai dengan Undang-Undang Nomor 23 Tahun 2014 dengan adanya desentralisasi maka muncul otonomi bagi suatu pemerintah daerah maka dengan hal ini tangung jawab pertumbuhan ekonomi suatu daerah bagaimana kepala daerah berperan sebagai garda terdepan untuk mesejahterakan warganya agar kemajuan suatu desa dan pertumbuhan ekonomi sekala besar akan tercapai (Wiranta 2015).

Kemudian peran kepala daerah untuk menciptakan lapangan pekerjaan bagi warga daerahnya yang kemudian warga daerahnya tidak sepenuhnya ketergantungan dengan nelayan saja tetapi masih bisa dengan ketergantungan dengan ekosistem lain untuk membangkit kesejahteraan desentralisasi dengan relevan. Hal ini setiap daerah dipimpin oleh kepala pemerintahan daerah. Kepala pemerintahan daerah pada tingkat kabupaten disebut bupati (Nuryanti 2015). Dalam menjalankan pemerintahannya kepala daerah pada tingkat kabupaten diberikan kewewenangan untuk mengurusi urusan pemerintahannya sendiri atau yang sering kita sebut dengan desentralisasi. Dengan demikian, prakarsa wewenang, dan tangung jawab mengenai urusan-urusan yang diserahkan tadi sepenuhnya menjadi tangung jawab daerah itu, baik mengenai politik kebijaksanaan, maupun mengenai segi-segi pembiayaannya.

Perangkat pelaksanaannya adalah perangkat daerah sendiri. Adapun bupati dalam melaksanakan tugas sebagai kepala daerah otonom, mempunyai kewajiban yakni: (a) mempertahankan dan memelihara keutuhan $\mathrm{NKRI}$; (b) memegang teguh pancasila dan UUD 1945; (c) menegakkan seluruh peraturan perundang-undangan; (d) meningkatkan taraf kesejahteraan rakyat; (f) bersama dengan DPRD kabupaten membuat peraturan daerah; (g) memimpin penyelengaraan pemerintahan daerah kabupaten berdasarkan kebijakan yang ditetapkan bersama DPRD kabupaten. 
Dengan poin-poin yang mengemukakan meningkatkan kesejahteraan rakyat maka pertumbuhan ekonomi maupun kemajuan desa suatu daerah adalah peran kepala daerah dalam mengordinir kesejahteraan rakyatnya dengan berbagai cara agar warganya merasakan kepedulian terhadap kepala daerahnya untuk memberikan politik kesejahteraan yang dia emban ketika sebelum menjadi kepala daerah sesuai program kampanye sewaktu pencalonan dahulu. Maka peran kepala daerah bukan hanya itu saja melainkan sebagai ayah dan ibu dari desentralisasi bagi warganya sehingga kepercayaan masyarakatnya masih tetap utuh dan percaya bahkan politik mampu membuat pertumbuhan ekonomi dan kemajuan desanya menjadi lebih baik dari sebelumnya (Wiranta 2015).

Pilkada merupakan kesempatan rakyat memilih pemimpin mereka. Serta memutuskan apa yang ingin pemerintah lakukan untuk mereka. Keputusan rakyat ini juga menentukan hak yang mereka miliki dan ingin mereka jaga. Maka kepala daerah sangat berperan penting dalam mengemban amanah yang diberikan kepada masyarakat daerah setempat untuk mewakili suara mereka dalam melakukan kebijakan yang seharusnya menumbuhkan kesejahteraan warga dalam kemajuan daerah maupun pertumbuhan ekonominya. Dengan hal ini bagaimana peran kepala daerah dalam menumbuhkan kompetensi ekonomi di daerah pesisir Batu BelubangBangka Tengah. Mengapa demikian karena sebagian dari penduduk Batu Belubang masih rentang dengan kemiskinan ekonominya maupun pembangunan daerahnya sehingga kajian penelitian ini untuk membangkitkan sumber sarana dan prasarana di daerah Batu Belubang - Bangka Tengah agar memiliki kebermanfaatan kepala daerah dalam membuka industri pengelolaan ikan menjadi sumber pangan mereka untuk menciptakan sarana dan prasarana yang baik dan berkualitas (Wiranta,2015).

Adapun rumusan masalah yang terdapat dalam penelitian ini merupakan kajian deskriptif yaitu bagaimana peran kepala daerah dalam meningkatkan kompetensi ekonomi di Bangka Tengah, dengan terpilihnya kepala daerah sematamata untuk menjadikan mutu pendidikan, mutu ekonomi yang sejahtera untuk penduduk yang dikhususkan di Bangka Tengah agar meningkatkan ekonomi penduduk di Kabupaten Bangka Tengah sehingga masyarakat mampu memberikan kontribusi terhadap anak-anak mereka dalam dunia pendidikan, dan mampu memberikan kebutuhkan ekonomi pangan mereka dalam mempercayakan kepala daerah yang mereka pilih. Sehingga seharusnya peran kepala daerah dalam menujangkan ekonomi maka dapat memberikan komposisi terhadap penduduk disana berupa lapang pekerjaan, dan kebutuhan lainnya. Sehingga terbukti kenerja kepala daerah dalam menyumbangkan kegunaan peran sebagai pemimpin di Kabupaten Bangka Tengah. Secara keterbukaan maka dapat menciptakan ketertiban yang saling menguntungkan agar tidak terjadi ketimpangan sosial antara pemimpin dan rakyat biasa. Serta menumbuhkan kualitas dari pada peran kepala daerah di pasar internasional dalam menumbuhkan ekonomi di kabupaten Bangka Tengah.

Menunjukan permasalahan di atas dapat dipungkiri bahwa perubahan ekonomi di Bangka Tengah setelah pergantian kepala daerah. Tentunya perubahan yang signifikan ini menjadi sebuah keadaan yang dahulunya menjadi hal yang banyak kekurangan semacam ekonomi menurun, pendidikan yang terbatas, lapang pekerjaan menjadi runtuh. Maka apakah hal-hal yang semacam ini sama setelah pergantian kepala daerah. Maka tak dapat dipungkiri hal ini akan terjadi lagi bila mana pemimpin acuh tak acuh dalam menjalankan roda kepemimpinannya untuk 
menumbuhkan sektor kompetensi ekonomi di pasca internasional. Tapi yang harus dipantau di sektor lokal atau daerah terlebih dahulu, bila mana ingin terkenal cara dan berbagai strategi memimpin suatu daerah. Maka bisa dilihat bagaimana kebahagiaan masyarakat Bangka Tengah khususnya penduduk pesisir Batu Belubang Bangka Tengah dalam menumbuhkan kompetensi ekonominya. Setelah pergantian kepala daerah, apakah masih sama dengan yang dulu atau janganjangan bertambah buruk.

Mestinya kita sadar sebagai agen perubahan dalam memimpin, tak terkecuali dengan persoalan yang sering terjadi dari hulu ke hilir yang tidak prnah kesudahan dalam persoalan ekonomi ini. Membangun boleh-boleh saja, tetapi harus banyak manfaat kepada penduduk yang berada di pesisir yang saat ini nelayan pun menjadi taruhan nyawa mereka untuk melaut. Agar bisa menyambungkan kehidupan mereka. Maka dengan ini peran kepala daerah harus benar-benar mampu melihat masalah yang terjadi. Bagaimana berfikir yang mampu membuat perekonomian ini menjadi acuan penting untuk penduduk. Maka ciptakan aneka-aneka yang penuh manfaat, seperti memperoduksi ikan tahan lama yang berupa seperti ikan asin, ikan dalam kaleng, atau membuat kuliner dari sebuah pendapatan nelayan untuk dijadikan mikro usaha kecil. Dengan dibantu kepala daerah sebagai perannya maka mampu produk-produk ini sampai ke pasar internasional. Maka dapat pula meningkatkan kompetensi ekonomi yang menjorong kebawah menjadi menjorong ke atas.

\section{EKONOMI POLITIK DALAM PILKADA}

Penelitian ini sangat relevan dengan isu yang terjadi di desentealisasi Batu Belubang - Bangka Tengah. Dari berbagai kurangnya kemajuan pembangunan desa maupun kompetensi ekonominya belum memadai sehingga masyarakat atau warga di daerah Batu Belubang masih banyak ketergantungan ekonominya dari sebuah pekerjaan nelayan. Kemudian penulis menemukan landasan teori yang mengenai peran kepala daerah terhadap kompetensi ekonomi warga pesisir Batu Belubang - Bangka Tengah.

Teori ini yakni patron-client: petukaran hubungan antara kedua peran yang dapat dinyatakan sebagai kasus khusus dari ikatan yang melibatkan persahabatan instrumental dimana seorang individu dengan status sosio-ekonominya yang lebih tinggi (patron) mengunakan pengaruh dan sumber dayanya untuk menyediakan perlindungan. Artinya klien berati bawahan atau orang yang diperintah dan yang disuruh. Selanjutnya pola hubungan patron-klien merupakan aliansi dari dua kelompok komunitas atau individu yang tidak sederajat, baik dari segi setatus, kekuasaan, maupun penghasilan, sehingga menepatkan klien dalam kedudukan yang lebih rendah (inferior), dan patron dalam kedudukan yang lebih tinggi (superior). Atau dapat pula diartikan bahwa patron adalah orang yang berada dalam posisi untuk membantu klien-kliennya.

Salah satu ciri hubungan patron-klien adalah adanya pola transaksi tertentu. Ada semacam rumus baku dari pola ini yaitu take and give, siapa yang memberi apa dan siapa yang mendapat apa. Ketika sang patron melakukan transaksi dengan sang klien maka ada kesepakatan antara mereka. Ada hubungan mutualisme dalam hubungan patron klien tersebut. Artinya dari pola hubungan patron klien ini maka semua sama-sama mendapat keuntungan yang timbal balik. Si patron mendapat apa yang diinginkan dari si klien, dan tentunya isi kesepakatan yang telah disetujui 
sebelumnya. dengan hal ini peran kepala daerah telah membuat masyarakat percaya dengan janji kampanye sebelum kekuasaan kursi politik diduduki dengan program yang manis untuk melabui rakyat jelata hingga saat ini desa Batu Belubang masih dikatakan jauh dari kemajuan desanya maupun kompetensi ekonomi yang masih ketergantungan dari nelayan dari berbagai warga yang telah di survei penulis.

Penelitian dari Muhimatul Khoiriyah, objek penelitian yang diangkat difokuskan peranan kepala desa dalam meningkatkan perekonomian masyarakat di bidang pertanian sedangkan penulis lebih mendeskripsikan terkait peran kepala daerah dalam meningkatkan kompetensi ekonomi warga pesisir Batu Belubang, Bangka Tengah. Dasar hukum yang digunakan Muhimatul Khoiriyah mengunakan Undang-Undang Nomor 32 Tahun 2004 tentang Pemerintahan Daerah dalam Peraturan Menteri Pertanian Nomor 16 Permentan OT.140/2/2008. Sedangkan penulis mengunakan Undang-Undang Nomor 32 Tahun 2004 tentang Pemerintahan Daerah (Lembaran Negara Republik Indonesia Tahun 2004 Nomor 125, Tambahan Lembaran Negara Republik Indonesia Nomor 4437), sebagaimana telah diubah beberapa kali terakhir dengan Undang-Undang Nomor 12 Tahun 2008 tentang Perubahan Kedua atas Undang-Undang Nomor 32 Tahun 2004 tentang Pemerintahan Daerah (Lembaran Negara Republik Indonesia Tahun 2008 Nomor 59, Tambahan Lembaran Negara Republik Indonesia Nomor 4844).

\section{METODE PENELITIAN}

Penelitian ini dilaksanakan melalui kajian litratur dengan pendekatan deskriptif dengan cara menganalisis bagaimana kesiapan kepala daerah sebagai peran penting terhadap menumbuhkan kompetensi ekonomi desentralisasi di Batu Belubang - Bangka Tengah dalam membangkitkan perubahan yang nyata bagi warga Batu Belubang - Bangka Tengah sehingga perbaikan-perbaikan kompetensi ekonomi menjadi lebih berkualitas dan kemajuan desanya pun semakin baik. Jenis penelitian ini mengunakan metode deskriptif kualitatif yaitu metode penelitian naturalistik karna penelitiannya dilakukan pada kondisi yang alamiah dikarenakan hasil survei yang dilakukan penulis terhadap keluhan masyarakat yang masih ketergantungan kompetensi ekonominya masih banyak dari pekerjaan nelayan sehingga membangkitkan sarana daan prasarana untuk kemajuan desenteralisasi Batu Belubang - Bangka Tengah ini masih tidak merata dari segi pertumbuhan ekonomi maupun sumber pangan dan berupa sarana dan prasarana desanya sendiri. Hal ini ditemukan survei dari penulis ada 1.619 jiwa yang terkonfirmasi pertumbuhan ekonominya ketergantungan dari pekerjaan nelayan dan tidak adanya sarana dan prasarana bantuan dari kepala daerah.

Kemudian waktu yang digunakan peneliti untuk penelitian ini dilaksanakan sejak tanggal kegiatan menjadi bagian dari penelitian KEK (Kawasan Ekonomi Kusus) yang dilaksanakan di Desa Batu Belubang - Bangka Tengah bersama istri rektor Universitas Bangka Belitung, yang kemudian bekerja sama dengan tim mahasiswa dari Universitas Diponegoro dalam kurun waktu kurang lebih 8 (delapan) bulan sekitar dari tanggal 30 September 2019 sampai 7 Oktober setelah selesai ikut serta dalam penelitian Kawasan Ekonomi Kusus di desa Batu Belubang - Bangka Tengah dan direkomendasikan oleh Dekan FISIP Universitas Bangka Belitung yaitu Ibrahim. Hal ini menjadikan bentuk hasil dari sebuah pengalaman yang didapat dan kemudian penulis menemukan keluhan masyarakat mengenai kompetensi ekonomi 
warga Batu Belubang sebagiannya masih ketergantungan dari nelayan serta kemajuan desanya pun masih kurang relatif memadai sehingga sarana dan prasarana yang diberikan oleh kepala daerah belum sepenuhnya terkonfirmasi kepada masyarakat. Tiga bulan pengumpulan data dan 5 (lima) bulan pengolahan data yang meliputi penyajian dalam bentuk analisis lapangan dan keluhan terhadap masyarakat atau warga yang masih belum disalurkan dana bantuan. Kemudian tempat penelitian ini dilaksanakan di lingkungan Desa Batu Belubang - Bangka Tengah dengan mengkajikan dan menganalisis peran kepala daerah terhadap perubahan kompentensi ekonomi dan pertumbuhan sarana dan prasarana yang seharusnya memadai hal ini terjadi di daerah dusun Batu Belubang - Bangka Tengah Kepulauan Bangka Belitung.

Penelitian ini mengunakan teknik analisis lapangan terhadap ketidak adanya bantuan dari perangkat kepala daerah sehingga pertumbuhan ekonomi banyak yang ketergantungan dari nelayan dan kemajuan desanya pun masih belum akurat, hal ini mestinya peran kepala daerah harus siap siaga dalam memperbaiki kualitas pertumbuhan kompetensi ekonomi dan kemajuan desentralisasi nya harus relevan dengan janji kampanye sebelum menduduki kursi-kursi jabatan di desentralisasi seperti teknik observasi yaitu pengamatan yang dilakukan secara sengaja, sistematis mengenai fenomena sosial dengan gejala-gejala psikologis untuk kemudian dilakukan pencatatan. Melalui tahapan observasi ini penulis ingin menggali data mengenai kesiapan kepala daerah sebagai peran penting dalam kemajuan ekonomi dan perbaikan suatu daerah sehingga menciptakan kesejahteraan warga dan melihat peran kepala daerah untuk memperbaiki kompetensi dana desa untuk kemajuan daerah dan memperbaiki sarana dan prasarana. Bahwa kepala daerah yang dipilih sewaktu pilkada menjadi acuan penting dalam memperhatikan kemajuan daerahnya maupun kesiapan ekonomi yang berkualitas yaitu mengalokasikan dana desa untuk kebangkitan ekonomi pangan maupun daerah tersebut.

Kemudian penelitian deskriptif ini bertujuan untuk menjelaskan suatu peristiwa yang oprasionalisasinya yang berkisar pada pengumpulan data-data dengan mengunakan validasi data yang diperoleh dalam fenomena tidak stabilnya kompetensi ekonomi yang menitikberatkan pada perubahan kompetensi ekonomi yang lebih baik dengan jangka panjang sekaligus membangun sarana dan prasarana desentralisasi yang berkualitas dan bermutu tinggi. Proses ini dapat dilakukan dengan cara wawancara pada objek penelitian dan observasi yang harus dilakukan guna mendapatkan data yang maksimal dalam peroses penyelesaian penelitian ini dan dapat melihat dari sebuah refrensi kajian litratur yang ditemukan di lapangan.

\section{PEMBAHASAN}

Kepala daerah merupakan seorang pemimpin yang dipilih oleh masyarakat untuk memperbaiki dan demi kemajuan daerah sebagaimana diamanahkan oleh seluruh masyarakat yang telah mempercayainya. Dalam hal perekonomian menjadi salah satu problem terus menerus dihadapi oleh seorang kepala daerah terpilih. Pembagunan ekonomi pada hakikatnya bertujuan untuk mensejahterakan masyarakat. Selama ini roda perekonomian perlahan membaik seiring dengan kemajuan dan pembagunan yang dilakukan oleh pemerintah, namun kenyataan 
tidak meratanya distribusi pembagunan ekonomi yang ditopang pemerintah sering kali mendapatkan komentar negatif dari masyarakat terhadap kinerja pemerintah.

Dalam mengatasi perekonomian masyarakat, berdasarkan analisis dari berbagai sektor yang menguji jumlah penduduk di Indonesia yang berdampak pada sektor kemiskinan pangan berupa sarana dan prasarana masih tidak setabil sampai detik hari ini. Sedangkan hasil survei lapangan yang merujuk pada penelitian ini yaitu dari berdasarkan data penduduk tahun 2014 berjumlah $1.106 \mathrm{KK}$ dan 3.238 penduduk. 1.619 jiwa yang terkonfirmasi pertumbuhan ekonominya ketergantungan dari pekerjaan nelayan dan tidak adanya sarana dan prasarana bantuan dari kepala daerah, yang terkhususnya di pesisir Batu Belubang, Kabupaten Bangka Tengah.

Masyarakat terpencil yang berada di pinggiran kota menjadi salah satu daerah yang mengalami kekurangan ekonomi dibandingkan dengan wilayah perkotaan. Hal ini dikarenakan pembangunan yang kurang serta susahnya akses untuk menjangkau daerah tersebut menjadi salah satu pemicu lambanya pembagunan perekonomian di daerah tersebut, tetapi untuk seorang kepala daerah dan atau pemimpin masyarakat daerah pinggiran tersebut harus terus diperhatikan guna mendapatkan kenyamanan dan kemajuan bagi masyarakat. Desa Batu Belubang Bangka Tengah menjadi salah satu daerah terpinggir Pulau Bangka yang harus menjadi perhatian khusus karena pembagunan yang kurang serta perekonomian yang di bisa dibilang kurang baik (Wiranta 2015).

Terjemahan dari teori patron-klien ialah menjelaskan bahwa dalam suatu interaksi sosial masing-masing orang melakukan hubungan timbal balik. Hubungan ini dilakukan secara vertikal (aktor yang mempunyai kedudukan yang tinggi). Istilah 'patron' berasal dari bahasa Spanyol yang secara epistimologis bearti orang yang memiliki kedudukan atau kekuasaan yang dapat diartikan power, wewenang, kedudukan, statu sosial yang tinggi di masyarakat serta mempunyai pengaruh besar terhadap suatu kegiatan, makna dari 'klien berupa perbedaan jabatan (Wiranta 2015).

Revolusi ekonomi seakan menjadi praktek yang terus terjadi dan kerap terjadi di kalangan masyarakat bawah. Hal ini sangat relevan melihat kondisi yang ada di daerah Batu Belubang dimana konsep desentralisasi tidak berjalan relevan dikarenakan masyarakat di Batu Belubang kurang mendapatkan perhatian oleh pemerintah padahal letak wilayah ini sangat strategis di wilayah pesisir pantai yang dominan masyarakatnya berpenghasilan dari laut. Jika pemerintah peduli terhadap pengalokasikan pertumbuhan kompetensi di kalangan masyarakat Batu Belubang yang selama ini sedikit luput dari perhatian pemerintah. Oleh karena itu peran pemerintah daerah sangatlah diperlukan dengan cara membantu masyarakat pesisir dengan pemberian bibit ikan, sosialisasi terhadap perternakan perikanan, lapangan untuk membudidaya ikan serta membuat semacam lapangan industri pengelolaan ikan yang baik untuk memaksimalkan pendapatan masyarakat dari hasil laut guna menopang roda perekonomian warga.

Pemerintah daerah mempunyai kebijakan dan wewenang untuk membuat suatu kegiatan yang bermaksud untuk mesejahterakan masyarakatnya. Tetapi nyatanya program pemerintah masih memiliki kendala pendistribusian yang kurang merata. Hasilnya banyak masnyarakat pro dan kontra terhadap kinerja yang dilakukan pemerintah daerah. Meski sampai sekarang pemerintah terus berupaya juga menjaga kestabilan ekonomi, pembagunan ekonomi serta kegiatan positif tetapi diharapkan setiap kegiatan atau program yang dijalankan tidak stagnan atau 
berjalan di tempat artinya kegiatan apapun harus di pantau juga mendapatkan hasil yang diinginkan (Sulaiman 2015).

\section{Keterlibatan kepala daerah dalam perubahan perekonomian}

Kemajuan suatu daerah tak lepas dari peranan sebagai kepala daerah. Pararelnya tugas sebagai kepala pemerintah daerah akan merujuk dalam seterategi untuk mesukseskan berbagai terobosan dan inovasi, serta cara yang terbilang sejahtera yaitu bagaimana mengalokasikan terhadap ide dan gagasan dan masyarkat untuk dijadikan program. Sehingga bisa membentuk cita rasa antara kepala daerah dan masyarakat dalam menjalankan roda kemajuan suatu daerah dalam kancah politik sewaktu pemilihan kepala daerah berarti demokrasi pilkada tercipta baik dan dapat dikatakan sukses. Dengan demikian apabila kancah politik pilkada tidak akurat dan tidak ditepati janji kampanye oleh kepala daerah maka hal ini kancah berpolitik akan berpengaruh dengan kepercayaan masyarakat terhadap kepala daerah selanjutnya sehingga masyarkat tidak menjaminkan politik mampu untuk mesejahterakan mereka ketimbang mereka harus ketergantungan dengan nelayan yaitu pekerjaan mereka. Dengan demikian peran yang harus dilakukan pemerintah kepala daerah menciptakan progam yang multi fungsi sehingga mengoptimalkan perubahan kompetensi ekonomi sehingga terprosesnya kenerja pembangunan atau kemajuan desa semakin meningkat dan kenerja kepala daerah dan jajarannya terbukti berperan aktif terhadap kepedulian ekonomi warganya ketimpang diri peribadi sehingga peran kepala daerah sebagai majikan dari tuan nya yaitu masyarakat dapat terodinir dengan baik (Wiranta 2015).

Peran kepala daerah dapat mewujudkan penderitaan warga Batu Belubang Bangka Tengah dalam memberikan perubahan baru terhadap kompetensi pertumbuhan ekonomi di dalam desa dengan demikian yang harus dilakukan kepala daerah yaitu membuat lapang pekerjaan lokal dalam memproduksi atau pengelolaan ikan mentah menjadi pendapatan kompetensi ekonominya bisa mendapatkan nilai lebih dari pengelolaan ikan yang dilakukan di lingkungan lokal daerah Batu Belubang. Mengapa demikian untuk mengurangi angka pengangguran dan sekaligus menciptakan peluang pendapatan baru terhadap warga nelayan dalam memperoduksi ikan nya sendiri sehingga nilai atau ciri has ini dapat terbukti bahwa desentarlisasi lokal menciptakan perubahan kompetensi ekonominya lebih meningkat di tinggkat nasional di kemudian hari atau dengan jangka panjang. Terbentuk dari sosial-ekonomi dapat diukur dari pergantian kepala daerah yang semestinya tidak berkembang dalam kompetensi ekonominya sehingga pada pilkada pemilihan kepala daerah baru menciptakan peluang ekonomi-politik di pasca perubahan pendapatan warga maupun kemajuan daerahnya dapat meningkat drastis, maka dengan hal ini warga percaya peran kepala daerah untuk mengakses perubahan baru dalam pertumbuhan ekonominya (Wiranta,2015).

\section{Kompetensi Ekonomi Warga Pesisir Batu Belubang-Bangka Tengah}

Melihat lanskap kesejahteraan warga dapat diukur dalam peningkatan ekonominya dalam mengalokasikan pendapatan menjadi penghasilan tetap sehingga masyarakat dapat mengurangi angka kemiskinan di suata daeraah atau disebut desentralisasi pendesaan. Tak lepas dari perjuangan kompetensi ekonomi warga Batu Belubang - 
Bangka Tengah apa bila pemerintah daerah tidak ikut campur dalam mewujudkan perubahan kompetensi ekonomi di daerah tersebut, dengan demikian peran kepala daerah harus peka terhadap sektor pertumbuhan kompetensi ekonomi dan pertumbuhan sektor kemajuan desentralisasi dengan cara membantu masyarakat dalam membentuk kerja sama yang nyata sehingga pertumbuhan kompetensi ekonomi menjadi acuan penting di suatu daerah dan dapat di buktikan bahwa politik mampu untuk membuat masyarakat sejahtera dalam perubahan gerakan yang nyata (Monica 2017).

Berbagai analisis maka terbukti dari hasil riset survei lapangan peneliti menemukan sekian persen masyarkat Batu Belubang-Bangka Tengah masih tergolong rendahnya pendapatan atau penghasilan serta tidak memiliki modal dalam mencari sumber daya alam seperti nelayan, berkebun. Dari sekian persen warga banyak yang mengeluh dan mempertanyakan bagaimana nasib kami yang tidak mendapatkan bantuan dari pemerintah daerah untuk memberikan modal ataupun bantuan yang membuat kami bisa nelayan dan bekerja semaksimal dan kemajuan desa batu belubang-bangka tengah pun masih belum dikategorikan baik dalam perubahan kemajuan daerah, hal ini dikarenakan terhambatnya kempetensi ekonomi yang membuat keadaan menjadi tidak stabil dalam melakukan usaha dan tidak meratanya pembangunan serta kompetensi ekonomi di daerah tersebut. Dengan demikian tabel dibawah ini bentuk dari hasil survei lapangan yang dilakukan observasi bentuk dari wawancara (Monica 2017).

Tabel 1 Analisis peran kepala daerah terhadap kompetensi ekonomi warga Batu Belubang-Bangka Tengah

\begin{tabular}{lll}
\hline $\begin{array}{l}\text { Jumlah } \\
\text { Penduduk }\end{array}$ & \multicolumn{2}{l}{ Peran Kepala Daerah } \\
\cline { 2 - 3 } & Hasil Survei & Ketergantungan \\
\hline 3.238 penduduk & $\begin{array}{l}1.619 \text { jiwa yang } \\
\text { terkonfirmasi }\end{array}$ & Nelayan \\
Tidak merata & $\begin{array}{l}\text { Laporan warga yang } \\
\text { bertumbuhan } \\
\text { belum mendapatkan }\end{array}$ & $\begin{array}{l}\text { Kompetensi ekonomi serta } \\
\text { sarana dan prasarana belum } \\
\text { memadai }\end{array}$
\end{tabular}

Tahun 2014-2019 Tahun 2019-2020 Tahun 1994-2020

Sumber: Database Kependudukan Nasional Ditjen dan Pencatatan Sipil Kementerian Dalam Negeri RI

Peran pemerintah kepala daerah sangat diharapkan oleh masayarkat daerah dalam membantu warga yang belum optimal dalam melakukan pengelolaan sumber daya alam sehingga dibutuhnya peran kepala daerah untuk melakukan perbaikanperbaikan terhadap perubahan kompetensi ekonomi di suatu daerah agar membentuk kesejahteraan masayarakat dalam proses pengelolaan sumber daya alam lokal. Tetapi ketika penulis melakukan surve ternyata masih banyak masyarakat daerah yang belum mendapatkan bantuan maupun perbaikan kemajuan desa sehingga hal ini harus di tindak lanjuti dengan secepatnya mengapa demikian karna buruknya sektor ekonomi masyarakat daerah yakni ketergantungan warga 
masih banyak berharap dengan penghasilan nelayan yang hanya cukup untuk makan saja tetapi hal ini pendidikan juga membutuhkan sarana dan prasana agar anak-anak mereka bisa menempuh pendidikan yang layak juga ucap salah satu warga batu belubang-bangka tengah pada tahun 2019 yang lalu (Monica 2017).

Pasca politik harus relevan dengan kebutuhan pangan warga agar mereka tidak melek politik ketika pilkada dilakukan sehingga partisipasi warga terhadap pemilihan umum yakni pemilihan kepala daerah membuat mereka percaya bahwa pemerintah daerah bisa melakukan perbaikan-perbaikan yang harus dilakukan di desa tersebut sehingga peran kepala daerah dapat di percaya dan akurat kenerja yang di sediakan oleh program sebelum kampanye dimulai sewaktu untuk merebut kursi-kursi politik yaitu kepala daerah dan mengoptimalkan segala keluhan masyarakat daerah demi kesejahteraan masyarakat daerah maka dana desa atau dana daerah dapat dilakukan dengan sebaik mungkin untuk pembangunan daerah serta menumbuhkan kompetensi ekonomi warga batu belubang-bangka tengah (Wiliam 2010).

Bercita-cita untuk mengembangkan penduduk desa dengan mesukseskan pilkada adalah salah satu bentuk partisipasi masyarakat yang ikut andil dalam suatu pemilihan dan mereka berharap kesejahteraan untuk penduduk daerah mereka dengan pergantian kepala daerah ini dapat meningkatkan segala mimpi dari pada penduduk kabupaten Bangka Tengah untuk mencukupi kebutuhan segala hal yang belum baik pada masa sebelum-sebelumnya. pilkada tidak bakalan sukses bila tidak ada partisipasi masyarakat dalam memberikan rasa percaya terhadap yang mengatur kebijakan daerah. Bukan hanya sekedar marketing politik dalam kampanye tetapi bagaimana membentuk dari peribadi untuk masyarakat bukan masyarakat untuk peribadi. Seperti itulah kira-kira kaca fakta yang terjadi di kalangan masyarakat saat ini, artinya mereka yang mencalonkan diri untuk menduduki pemerintah semata-mata banyak yang melabui rakyat. Setelah jadi dan punya kuasa maka mereka-mereka itu akan metengelamkan masyarakatnya.

\section{KESIMPULAN}

Persoalan di atas masih banyak laporan dari warga yang belum mendapatkan bantuan secara adil. Karena masih banyak terdapat birokrat yang memegang jabatan di pemerintah daerah hanya mementingkan sekelompok saudara-saudari mereka saja yang sering diperhatikan dan diberikan bantuan, yang bukan kerabat terdekat maka akan sulit untuk diberikan bantuan perekonomian bahkan sarana dan perasarana pendidikan saja masih terbengkalai yang semestinya mereka para anakanak nelayan dalam membutuhkan pendidikan yaitu hak mereka untuk belajar saja masih sulit seperti kekurangan seragam sekolah, akses berpergian ke tempat sekolah. semata-mata hal ini disebabkan karna ekonomi yang tidak cukup adil terhadap mereka yang miskin. Sehingga hanya berpihak kepada orang-orang tertentu yang memiliki kepentingan semata di pemerintah daerah. Makanya guna dari peran kepala daerah yang baru, masyarakat berharap agar ada perubahan dalam melihat keadilan dalam memberikan bantuan kepada siapapun sehingga tidak pandang bulu artinya siapapun masyarakat yang berada di Kabupaten Bangka Tengah kususnya di Batu Belubang warga desa pesisir berhak untuk diberikan bantuan secara merata dan adil. Sehingga akan mengurangi konflik antar warga pesisir di Desa Batu Belubang. 
Kesejahteraan masyarakat ialah salah satu bentuk dari peningkatan kompetensi ekonomi warga untuk memberikan kesejahteraan pangan dan sarana maupun prasarana kebutuhan sosial dan lingkungannya. Peran kepala daerah harus bisa merujuk bantuan sarana dan perasarana terhadap warga daerah agar peran kepala daerah dapat berfungsi bahwa kepala daerah memperhatikan masyarakatnya dalam pertumbuhan ekonomi. Dari hasil penelitian dapat diartikan bahwa masih banyak warga yang belum terkoodinir oleh kepala daerah dalam memberikan bantuan serta mengoptimalkan kompetensi ekonomi dalam mewujudkan perubahan nyata dari pemerintah daerah yang sebagai peran penting menjadi kepala daerah dalam menciptakan hal-hal yang baru untuk mesejahterakan warga daerahnya sehingga merujuk pada pertumbuhan kompetensi ekonomi yang baik dan berkualitas di pasca lokal maupun nasional dengan jangka panjang.

Peran kepala daerah terhadap perubahan kompetensi ekonomi warga pesisir Batu Belubang-Bangka Tengah yang berdasarkan data penduduk tahun 2014 berjumlah 1,106 KK dan 3,238 penduduk. 1.619 jiwa yang terkonfirmasi pertumbuhan ekonominya ketergantungan dari pekerjaan nelayan dan tidak adanya sarana dan prasarana bantuan dari kepala daerah yang terpilih di Kabupaten Bangka Tengah, kemudian pada tahun 2020 menjelang pilkada yaitu pemilihan kepala daerah Kabupaten Bangka Tengah dengan harapan dapat mengubah sektor ekonomi di Bangka Tengah khususnya di desa batu belubang warga pesisir yang sering kali sulit mencari ekonomi yang hanya berharap pada nelayan. Acuan penting dalam pertumbuhan ekonomi di Desa Batu Belubang sering kali dapat dibuktikan dari kecerdasan seorang kepala daerah dalam meningkatkan perekonomian daerahnya sekaligus mengunakan perannya sebagai kepala daerah untuk memberikan asumsi ekonomi pangan terhadap kebutuhan rakyatnya. Dengan tujuan untuk mengetahui betapa pentingnya peran kepala daerah terhadap program kerjanya dalam memanfaatkan peran dan fungsinya sebagai pemimpin wilayah dalam mengembangkan sektor perekonomian dengan bijaksanan dan adil.

\section{REFERENSI}

Agustamar, Mouzar. (2014). Resstruktursasi Birokrasi dan Pengembangan Good Govermance (Aspek Kompetensi Administrasi, Transparansi dan Efisiensi dalam Restrukturisasi Birokrasi Pemerintah Kota Tanjung Pinang). Jurnal Administrasi Publik dan Birokrasi, Vol. 1, No. 1.

Angraini, Yuni. (2018). Peran Kepala Daerah dalam Pembangunan Infrastruktur. Jurnal University Lampung. 4-6.

Basri, Seta. (2011). Pengantar IImu Politik. Jogjakarta: Indie Book Corner.

Bawanda, Wiliam. (2010). Peran Kepala Distrik Dalam Meningkatkan Perekonomian Masyarakat di Distrik Makbon Kabupaten Sorong. Jurnal Jurusan IImu Pemerintahan 49, 134-245.

Dermawan, Windy. (2019). Partisipasi Politik. Depok: Rajagrafindo Persada.

Djuyandi Yusa. (2019). Partisipasi Politik dan Etnisitas studi pada Etnis Dayak U'UD danum. Depok: Rajawali Pers.

Frinces, Z. Heflin. (2013). Membangun Ekonomi Daerah di Indonesia. Jurnal Ekonomi. Vol.4. No. 2.

Gaffar, Janedjri. M. (2012). Politik Hukum Pemilu. Jakarta: Konstitusi Press. 
Hasan, Muhammad. (2018). Pembangunan Ekonomi dan Pemberdayaan Masyarakat (startegi pembangunan manusia dalam perspektif ekonomi lokal). UNM: CV. Nur Lina.

Indus Noh Jafar, dkk. (2019). Optimalisasi Peran Kepala Daerah di Pemerintahan Kota Tidore Kepulauan. Jurnal Eksekutif, Vol. 3. No. 3.

Monica, Ayu Clara. (2017). Analisis Potensi Sebagai Upaya Meningkatkan Prekonomian Daerah di Sumatera Bagian Selatan. Jurnal Ekonomi Pembangunan, Vol. 15 (1): 60-68.

Muhimatul Khoiriyah, Skripsi: peranan kepala desa dalam meningkatkan perekonomian mayarakat di bidang pertanian, Tanjungpinang, UMRAH. 2018.

Nuryanti, Sri. (2015). Intervensi Penyelengaraan Pemilukada; Regulasi, Sumberdaya dan Eksekusi. Jurnal IImu Sosial dan IImu Politik, Vol. 19. No. 2. (November).

Ridwan. (2017). Perencanaan Pembangunan Daerah. Bandung: Alfabeta.

S. Alisjahbana, Armida. (2013). Memperkuat Perekonomian Domestik bagi Peningkatan dan Perluasan Kesejahteraan Rakyat. Jakarta: Kementerian Perencanaan Pembangunan Nasional/Badan Perencanaan Pembangunan Nasional.

Sparringa, Daniel. (2016). Demokrasi. Surabaya: Averroes Press.

Sulaeman, Affan. (2015). Demokrasi, Partai Politik, dan Pemilihan Kepala Daerah. Jurnal Ilmu pemerintahan, Vol. 1. No. 1.

Undang-Undang Dasar Negara Republik Indonesia Tahun 1945

Undang-Undang Nomor 5 Tahun 2003 Tentang Pembentukan Kabupaten Bangka Selatan, Kabupaten Bangka Tengah, Kabupaten Bangka Barat, dan Kabupaten Belitung Timur di Provinsi Kepulauan Bangka Belitung (Lembaran Negara Republik Indonesia Tahun 2003 Nomor 25, Tambahan Lmebaran Negara Republik indonesia Nomor 4268).

Undang-Undang Nomor 32 Tahun 2004 Tentang Pemerintahan Daerah (Lembaran Negara Republik Indonesia Tahun 2004 Nomor 125, tambahan Lembaran Negara Republik Indonesia Nomor 4437), sebagaimana telah diubah beberapa kali terakhir dengan Undang-Undang Nomor 12 Tahun 2004 Tentang perubahan kedua atas Undang-Undang Nomor 32 tahun 2004 Tentang Pemerintahan Daerah (Lembaran Negara Republik Indonesia Nomor 4844).

Wiranta, Dayat NS. (2015). Penguatan Peran Pemerintah Daerah Dalam Mendorong Pertumbuhan Ekonomi Lokal: Peluang dan Tantangan Masyarakat Ekonomi ASEAN (MEA). Widyaiswara Network Jounal. 33-50. 